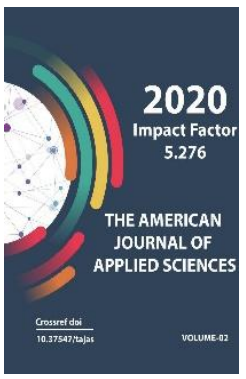

\title{
Genetic Types Of Rare Mineral Gold Of Western Uzbekistan (Southern Tien-Shan)
}

\author{
Razikov Odil Takhirjanovich \\ Candidate of Geological and Mineralogical Sciences, Chief Researcher, State Enterprise \\ Institute of Mineral Resources SE "IMR", State Committee for Geology of the Republic of \\ Uzbekistan, Tashkent city, T. Shevchenko st. 11a., Uzbekistan
}

\begin{abstract}
Journal Website: http://usajournalshub.c om/index,php/tajas

Copyright: Original content from this work may be used under the terms of the creative commons attributes 4.0 licence.
\end{abstract}

\section{ABSTRACT}

The work describes the genetic types and conditions for the localization of mineralization - individual deposits and ore occurrences. Also, the indicated mineralized zones, the conditions of occurrence of the mineralization, the geological-structural position and the peculiarities of the host complexes. Descriptions of promising tungsten, tin ore, polymetallic, mercury and other ore zones, which serve as a reserve in expanding the resource base in the Republic, are given. Tungsten, tin ore, and mercury mineralizations are characterized in somewhat more detail, since the latter in the region under study is often spatially associated with gold and forms mercury-antimony-polymetallic mineralization.

\section{KEYWORDS}

Conditions of formation, patterns of distribution, gold ore, tungsten, tin ore, pyritized, silicified, sphalerite, chalcite, molebdinit.

\section{INTRODUCTION}

At present, Western Uzbekistan is considered one of the most promising for gold, silver, tungsten, tin, mercury, antimony, lead-zinc, uranium and other minerals in the Central Asian ore province. As a result of the work of a large team of geologists - production (Goskomgeology, Navoi and Almalyk mining and metallurgical combinat (MMC)) and scientific institutions (Institute of Geology and Geophysics of the Academy of Sciences of Uzbekistan, Institute of Mineral Resources, etc.), numerous deposits and ore occurrences have been explored: pegmatite-rare-metal (Ketmenchi, Zirabulak, Kutchi ); pegmatitequartz-feldspar (Mulla-Burkhan, Kyz-Kurgan, etc.); greisen-rare metal (Sulu-Kyz, Tadyknaya, 
Kurai, Kara-mosque, Berkut); skarn-rare metal (Ingichka, Lyangar, Koitash, Yakhton, Karatyube, Sarutau, Sautbay, Daray-tut, Uchmulla, Maizak, Yarmakchi, Guljan, Tym, Mulla-Burkhan, Buzgulgryada, Chuyun); skarntin-polymetallic (Kyz-Kurgan); skarn-leadantimony (Kaltasai); hydrothermal-gold-oremetasomatic (Muruntau, Kokpatas, Tillatag, Dilan, Korakutan, Granitnaya, Yangi Davon, Pistal, Azhibugut, etc.); hydrothermal tin ore (Kochkarly, Lapas, Karnab, Kermene, Changalli, Devonasai, Kalta, Temirkan, Dzhilansay, Gaulinskoe, Karakuduk, Sukaiti,
Chaidaroz, Tutak, Altyn-Kazgan); hydrothermal-copper metal (Miskan, Atkamarsay); hydrothermal-mercury (KazanBulak, Altyaul, Vostok-I and II, Plot - I, Kurgancha, Dzhilga, Karasu (Malguzar), Kushkumbai (Tamdytau), Yubileinoe-1 (Kuldzhuktau), Tumshuk, Dzhalgiz (Beltau), etc.) $[1,5,8,9,12,14,15]$.

The object of the study is the territory of the part of the Southern Tien Shan, which is located in Western Uzbekistan with deposits and ore occurrences of gold and rare-metal mineralization (Fig. 1).
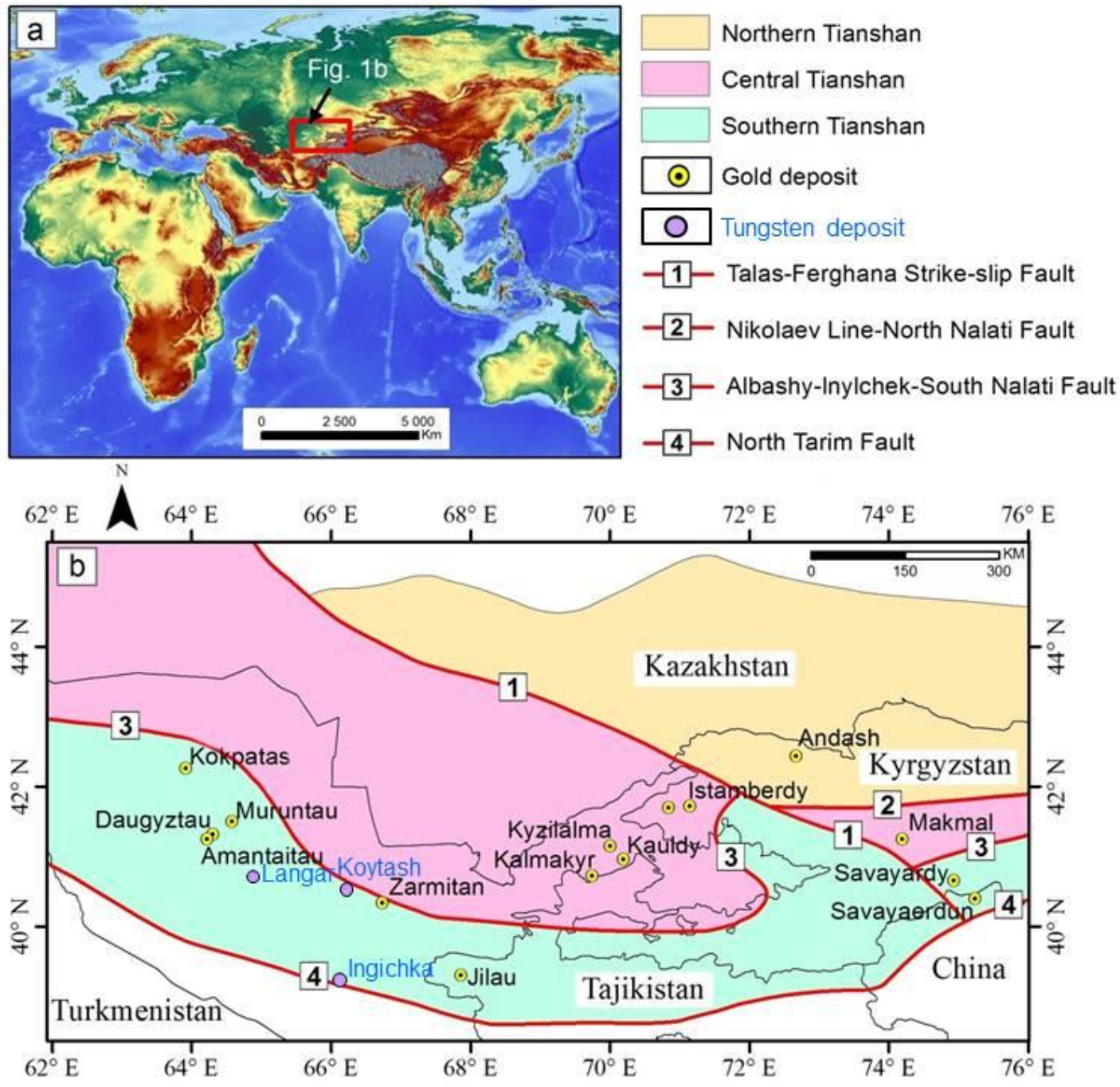

Fig. 1. (a) Map of digital elevation model of the world (b) Geological map of part of the territory of the South Tien Shan orogen in Central Asia (modified after Lei et al., [10].; Goipov et al., [7]). 


\section{MATERIALS AND METHOD}

Questions of geology, conditions of formation and patterns of distribution of mineralization were covered in the works of many researchers $[2,4,6,11]$. Therefore, the article describes only the genetic types and conditions for the localization of mineralization - individual deposits and ore occurrences.

Among the known ore occurrences of the region, gold, tungsten, tin ore, mercury, antimony and rare-metal deposits are of the greatest practical interest.

Below, we will dwell in more detail on the characteristics of the manifestations of tungsten mineralization, since the latter in the region under study is often spatially associated with gold ore and especially for forecasting with mercury and mercuryantimony-polymetallic mineralization. With their genetic link to tungsten. A similar mineral association is found in the Caucasus, Transbaikalia, in the southern provinces of China and other regions. A certain paragenetic relationship is also noted between tin ore and mercury-antimony mineralization.

Tungsten mineralization. Uzbekistan occupied one of the leading places in the production of tungsten ores in the 70s of the XX century. Industrial tungsten deposits are concentrated within Western Uzbekistan (Ingichka, Lyangar, Koytash, Yakhton, Karatyube, etc.), among which many deposits are fully or partially worked out. Within the study area, significant accumulations of tungsten mineralization are concentrated in skarn zones and ore formation is associated with skarn formation. Skarn-ore deposits and ore occurrences are represented by limestone and, in small quantities, magnesian formations.

\section{RESULTS AND DISCUSSION}

Calcareous skarn formations are composed of pyroxene (gedenberget), pyroxene-garnet (grossular-andradite) and pyroxene-garnetwollastanite mineral types located at the contact of granitoids and marbles. The most powerful development of scheelite-bearing skarns was obtained in the Zirabulak regions Ziaetda, Chakilkalyan, Karatyubinsk, Nurata, Bukantau, Arestantau and Kuldzhuktau mountains, where more than a dozen industrial tungsten deposits have been explored. In addition to scheelite, skarns (Ingichka, Lyangar, Koitash, Yakhton, Karatyube, Darai-tut, Uchmulla, Maizak, Yarmakchi, Guljan, Tym, Mulla-Burkhan, Buzgulgryada, etc.) contain: pyrrhotite, tin minerals (cassiterite, stanin tillite), galena, sphalerite, chalcopyrite, pyrite, molebdinite and other ore minerals. They have an increased concentration of impurity elements: bismuth, gold, silver, tellurium, tin, etc., which makes it possible to recommend the complex use of ores.

A much smaller scale than Ingichka, Koytash, Lyangar, Yakhton is the Chuyunskoye deposit, as well as industrial and related objects with tungsten trioxide content are noted in some areas of contact skarn bodies. In the ore occurrences of Shar-Shara, Rabanjan Changalli, Beshtal, Mulla-Burkhan, Sarutau, Sautbai, Devona-say, chalcopyrite plays the leading role of ore minerals. Here, in the skarnated hornfels, in some places there are high gold contents, increased concentrations of silver and some other elements.

Thus, the above ore occurrences, according to the conditions of the occurrence of mineralization, geological and structural position, and the peculiarities of the host complexes, together form promising tungsten ore zones, which serve as a reserve in expanding the raw material base of tungsten in the Republic.

Magnesian and apomagnesian calcareous skarns are noted in the northern exocontact of the Zirabulak intrusion. They are represented by diopside varieties; they form 
sheet-like and lenticular bodies in dolomites. Other varieties are represented by amphibolepyroxene, thermolitic, forsterite-diopside and similar skarns in composition, developing mainly along dolomite, dolomitized limestones and some horizons of the shale strata in the southern part of the region (Tym, Dzhin, Kizkurgan, Kaltasay ore occurrences).

Apomagnesian - calcareous skarns, which formed due to the transformation of magnesian skarns of the magmatic stage, are represented by their mineral composition: scheelite, galena, sphalerite, arsenopyrite, cassiterite, tellite, bismuthine, pyrrhotite, etc. They contain trace elements: silver in galena $\mathrm{n}$ / $\mathrm{t}$, in sphalerite $\mathrm{n} 10 \mathrm{~g} / \mathrm{t}$ and bismuth and tin are found slightly in hundredths of a percent. When studying the peculiarities of the mineral composition of the apomagnesian-calcareous skarns of the Ingichka ore field, their connection with the Kattasaykiy fault was revealed, at the southern end of which the skarn-tin-polymetallic ore occurrences Kaltasai and Kizkurgan are located, which are similar in composition.

A rather wide complex of ore minerals (scheelite, molybdenite, arsenopyrite, sphalerite, galena, magnetite, etc.) is established in the skarns of Tyma, however, at this stage, none of them forms industrial accumulations.

Conditioned contents of tungsten trioxide and other metals are recorded in separate areas of the Kyzkurgan, Kaltasaya and Zirabulak skarn bodies and other ore occurrences.

All skarn bodies of the area are spatially associated with granitoid intrusions of the Upper Carboniferous - Lower Permian (C3-P1) and are localized either in their direct contact with carbonate host rocks or in the exocontact zone.

The most favorable environment for the formation of scheelite-bearing skarns is limestone and, in particular, dolomite limestone.

In the formation of skarn bodies, two types of structures should be distinguished: ore-mixing structures, with which the placement of skarn is directly related and ore-bearing solutions along which ore-bearing solutions come from the centers of their origin to the places of localization.

Thus, the formation of scheelite-bearing skarns is determined by combinations of magmatic, lithological, and structural factors and the role of host rocks in the location of mineralization.

\section{Tin mineralization}

In contrast to tungsten mineralization, tin is found in the region in various mineral forms. Only a few tin ore deposits are known, but tin is sometimes present in noticeable quantities in tungsten deposits and forms a general broad scattering background in various types of intrusive as well as postmagmatic altered rocks. Thus, at the Changalli deposit, greisenized granodiorites accompanied in places by albitized Ingichke granitoids were found to have high scheelite concentrations.

In the aisles of the region, greisen, pegmatite genetic types of ores and associated tin ore rare-metal, rare-earth, etc., mineralizations are poorly studied, in connection with which it is necessary to carry out revision assessment work on the above-mentioned minerals. Among the sedimentary-metamorphic rocks in the aisle of the region under consideration (the eastern and southern parts of Zirabulak Ziaetdinsky, Chakyllyansky, Karatyubinsky, Nurata, Bukantau, Arestantau and Kuldzhuktau mountains), hydrothermally altered dikes of laprophyrs, porphyry granite diorite, molybdenite, scheelite, gold and other minerals. However, commercial accumulations of cassiterite are found only in modified Laprophyre dikes (Lapasa). Apparently, the dikes had a precipitating 
effect on the tin precipitated from the solutions circulating along the cracks in the limestones.

Quartz veins, widespread in the region, contain scattered dissemination of cassiterite, scheelite, pyrite, chalcopyrite, galena, sphalerite, molybdenite and other minerals.

Industrial and prospective accumulations of some of them differ in part of quartz veins located among the granitoids of Changalli, Altyn-Kazgan, Sulu-Kyz, Taryknaya, Kurai (cassiterite), Ingichka, Koytash, Yakhton, Karatyube, Lyangar, etc. (scheelite), Gurulyaksay , Shushchaktau, Karatyube (galena), etc.

Pyritized, silicified and weakly silicified dolomite rocks in some places bear tin, polymetallic and other types of mineralization. So, sporadic, but rather large allocations of cassiterite are found in altered dolomites (Kachkarly, Kyz-Kurgan, Kyzil-Gura, Kaltasaya and Lapasa).

Pegmatites with an insignificant content of cassiterite are noted in a number of veins of Ketmenchi, Kutchi, Karamechet and Berkut.

The main ore-bearing and ore-controlling structures in the aforementioned ore occurrences and deposits in all cases are small and large faults. Thus, within the described region, according to the data of previous researchers and according to the results of our work, the following tin ore formations can be distinguished: pegmatite, cassiteritequartz, carbonate- cassiterite formation. This formation includes deposits (Changaly, Karnab, Lopas, Altyn-Kazgan and Kermene), as well as a number of small occurrences associated with quartz veins.

Lead - antimony mineralization. A typical representative of the deposits of this ore formation is Keltasayskoe in the Zirabulak mountains. It gravitates towards the southwestern part of the Zirabulak intrusive massif, composed of felsic rocks. Directly orebearing rocks - altered (skarnated, silicified) dolomites, limestones and shales.

Ore bodies are small veins confined to steeply dipping fractures that develop in the exocontact zone of stocks and dikes.

Primary ore minerals were, apparently, complex sulfasalts: exploration workings uncovered only the bodies of massive oxidized ores containing high amounts of lead, antimony, zinc, copper, tungsten trioxide, tin and silver.

Deposits of lead-antimony ores from hydrothermal solutions occurred at the junctions of ruptures with gently dipping cracks in the soda part of the anticlinal structure.

\section{Mercury mineralization}

A number of ore occurrences of cinnabar (Dzhilga, Kazanbulak, Vostok-I, Dalniy, Karasu, Pastkucha, Konchoch, Yubushkushkoye, Myk, Dzhalgiz, Kurgancha, Altyaul including four mineralized points that make up a single Altyaul ore field). The main structural element of the latter is the Altyaul anticline. The strike of the fold is northwestern, close to latitudinal. This structure is complicated by folding of smaller orders.

The most favorable ore-bearing rocks are dolomites, dolomitic limestones and limestones [13, 16, 17]. Much less mercury mineralization is found in shales and sandstones. Hydrothermal changes within the ore field affected all varieties of ore-hosting rocks.

\section{CONCLUSION}

In conclusion, it should be noted that most of the deposits and ore occurrences known within Western Uzbekistan seem to be very promising and, of course, deserve further comprehensive research and geological exploration. 
In terms of the study area, dolomitization of limestone can be attributed to widely developed processes. Ore bodies are lenticular, nest-shaped. the main ore mineral is cinnabar, accompanied by calcite, dolomite, and rarely pyrite.

Previously identified manifestations must be studied in detail using new requirements for geological exploration work and revision and appraisal work should be carried out in promising areas.

Based on the needs of the Republic of Uzbekistan in mineral raw materials, it is necessary to return to the study of strategically important minerals - for goldsilver, tungsten, tin, mercury - antimony, lead zinc, etc.

\section{REFERENCES}

1. Abdullaev Kh.M. Collected Works. Volume U1. - Tashkent, publishing house "Fan" UzSSR, 1967, 302 p.

2. Aisanov Ya.B. and others. Geological structure and main features of minerageny of the Paleozoic formations of the Kuldzhuktau mountains.-T .: Fan 1978.- $120 \mathrm{p}$.

3. Akbarov Kh.A. Geological and structural positions of ore fields and deposits of the Tien Shan, positions as search criteria. // Geology and Mineral Resources. 2004, No. 5, pp. 18-28.

4. Akhundzhanov R., Zenkova S.O., Karimova F.B. Distinctive features of ultramafic-basic intrusions of various ore content (Western Tien Shan). // Geology and Mineral Resources. -2015. - No. 3, pp. 11-26.

5. Baymukhamedov Kh.N. and others. The main features of endogenous metallogeny in Uzbekistan. // Proceedings of Metallogeny of the Tien Shan. Frunze: ILIM Publishing House, 1968. pp. 191-194.
6. Garkovets V.G. Structural-metallogenic zoning and prospects of some types of endogenous mineralization in Uzbekistan. -Tashkent, The report was submitted for the degree of candidate of geological and mineralogical sciences based on the totality of published works. 1971, $75 \mathrm{p}$.

7. Goipov, A. B., Rakhmatovich, K. N., Axmadov, Sh. I., \& Musaxonov, Z. M. (2020). Application of Ratio Bands of Space Images For Mapping Minerals On The Example Of Kokpatas-Okzhetpes Trend In Mountain Bukantau (South Tien Shan). The American Journal of Applied Sciences, 2(07), 94-103. https://doi.org/10.37547/tajas/Volume02ls sue07-16

8. Golovanov I.M. Geological and industrial types of primary deposits of gold in Uzbekistan // Geology and mineral resources. - 2000. - No. 1. - pp. 18-30.

9. Karabaev M.S. and others. Problems of using geochemical data to identify the genesis and development of prospecting and evaluation criteria for mineralization /l International Scientific and Practical Conference. Actual problems of oil and gas geology and innovative methods and technologies for the development of the hydrocarbon potential of the subsoil. Tashkent: 2019. - pp. 349-354.

10. Liu, Lei \& Feng, Jilu \& Han, Ling \& Zhou, Jun \& Xu, Xinliang \& Liu, Rui. (2018). Mineral mapping using spaceborne Tiangong-1 hyperspectral imagery and ASTER data: A case study of alteration detection in support of regional geological survey at Jintanzi-Malianquan area, Beishan, Gansu Province, China. Geological Journal. 53. 372-383. 10.1002/gj.3260.

11. Mirkamalov R.Kh., Chirikin V.V. and other Atlas of models of ore deposits in Uzbekistan. - Tashkent. - NIIMR, 2010 .$100 \mathrm{p}$.

12. Pirnazarov M.M. Gold of Uzbekistan: Oreformational types, predictive-prospecting 
models and complexes. Tashkent State Enterprise "IMR", 2017, 248p.

13. Razikov O.T. and others. On the factors of ore localization of mercury formations in Uzbekistan - as a basis for forecasting promising areas. // "XIII International Scientific Conference". "New ideas in earth science" M .: 2017 - pp. 237-238.

14. Razikov O.T. and other Geological and structural factors of localization of gold mineralization in the Kuldzhuktau mountains. O'zbekiston Konchilik xabarnomasi No. 2 (77) 20193. - pp. 25-27.

15. Sadikova L., Kasimova SH., Maripova S., Abduazimkhodjaev A. Regional metallogenic analyst issuing mathematical statistics method (Nurataregion, Uzbekistan) // International Journal of Geology, Earth and Environmental Sciences. Center for info Bio Technology. Jaipur, India, MayAugust 2016, -Volume 6 Number 2. -pp. 111-115.

16. Fedorchuk V.P. Metallogeny of mercury and antimony. // Proceedings of Metallogeny of the Tien Shan. Frunze: Publishing House "ILIM", 1968. pp. 300301.

17. Tsoi V.D. et al. Prospects for the metal content of carbonaceous rocks in Uzbekistan // "International scientific and practical conference". Actual problems of oil and gas geology and innovative methods and technologies for the development of the hydrocarbon potential of the subsoil. - Tashkent: 2019. pp. 452-456. 